\title{
Service Audit in Filling Annual tax Return Using The Cobit 5 Framework at Tabanan Primary Tax service Office
}

\author{
Ilham Anggit Hadi Pradana \\ Department of Information \\ Technology \\ Faculty of Engineering \\ Udayana University \\ Badung, Bali, Indonesia
}

\author{
Dwi Putra Githa \\ Department of Information \\ Technology \\ Faculty of Engineering \\ Udayana University \\ Badung, Bali, Indonesia
}

\author{
I Putu Agung Bayupati \\ Department of Information \\ Technology \\ Faculty of Engineering \\ Udayana University \\ Badung, Bali, Indonesia
}

\begin{abstract}
An application of information technology in a company is important in order to make the company better. The information technology can support the achievement of the company's strategic plan to be aligned with its vision, mission and goals. Tabanan Primary Tax Service Office is a company as the example of the application of information technology for this research. The application in that company needs to be regulated, therefore it can be put to good use. In regulating information technology, an audit is needed which aims to evaluate and ensure compliance with the objective approach of a standard. The service audit in filing annual tax returns by using the COBIT 5 framework at the Tabanan Primary Tax Service Office is a form of audit to find out the IT processes that exist in the office. This audit was conducted to determine the level of maturity of the existing IT processes in the service of filing annual tax returns, whether it has been used properly and optimally based on COBIT 5 . The audit analysis process performed to obtain capability results, such as the DSS 02, DSS 03, DSS 05, and APO 12 domains. Recommendations and suggestions for improvement of the results obtained are done using the COBIT 5 standard.
\end{abstract}

Keywords: Information Technology, Tabanan Primary Tax Service Office, COBIT 5.

\section{INTRODUCTION}

Information systems in a company or organization must be implemented because it has a positive impact and can improve performance to support business processes. The accuracy and speed of information are needed to help the decision making process, especially the strategic one.

The Primary Tax Service Office is a work unit of the Directorate General of Taxation that performs services in the field of taxation. Taxpayers have annual obligations, namely Annual Tax Return which is a tax report regarding the calculation, tax payment, object or non-object tax as well as the rights and obligations in accordance with the provisions submitted to the Indonesian government through the Directorate General of Taxation. All taxes are regulated by the Law of the Republic of Indonesia Number 36 of 2008. One of the information systems exist in the Primary Tax Service Office is E-Filing, which is an information system application that can be used by taxpayers in filing data input of annual tax return. There are some problems that often occur due to the negligence of the recording operator and the error of reporting data from the taxpayer, such as the error of taxpayer data input, loss of taxpayer data, miscalculation between the system and manual calculation, stacking of tax paper that has not been recorded by the operator. Therefore, an audit of all aspects related to the E-Filing information system is required. An information system audit is developed with the aim of avoiding fraud and knowing the extent to which the implementation of the system is in accordance with the objectives, as the result a good governance is created. A method used in conducting the information system audit process is the COBIT (Control Objective for Information and Related Technology) framework. The COBIT framework was chosen because it provides practice standards of information technology management and internationally accepted references. In addition, it presents steps that are easily accepted and understood by auditors, managers, and system users in utilizing the application of information technology in an organization. The information systems management in EFiling can use the COBIT framework, because it helps to fulfill the various management needs of information by bridging the gap between business risk, control and technical issues[1].

\section{LITERATURE REVIEW}

A previous study about information technology audit by using the COBIT 5 framework has previously been developed for state electricity companies entitled "Audit Capability EAM using COBIT 5 and ISO 55002 in State Electricity Companies" by Ni Kadek Ayu Widya Utami. It explains that the audit capability is performed to determine the maturity of the system and the condition of existing management, as well as to provide recommendations for improvement using COBIT 5 and ISO 55002 [2].

I Wayan Prasada Bharaditya has also conducted a research related to information technology audits for cooperative management by using the Cobit 5 framework. The study entitled "Internal Control Improvement for Creating Good Governance" explains about information technology audits performed on cooperatives to overcome problems or critical points and to support the achievement of optimal information technology governance by using the COBIT framework [3].

\section{RESEARCH METHODS}

The research method is the basic stages performed in conducting a research. It aims to make the research process more organized, systematic, controlled and directed. Planning in a study is needed, therefore it is directed and has a right target. 


\subsection{The Stages of the Information Technology Audit Process}

The process stages are conducted, therefore the audit process is performed systematically and on target. The stages of the service audit process in filing annual tax returns at the Tabanan Primary Tax Service Office by using the COBIT 5 framework consists of 8 main stages. The stages are shown in Figure 1.

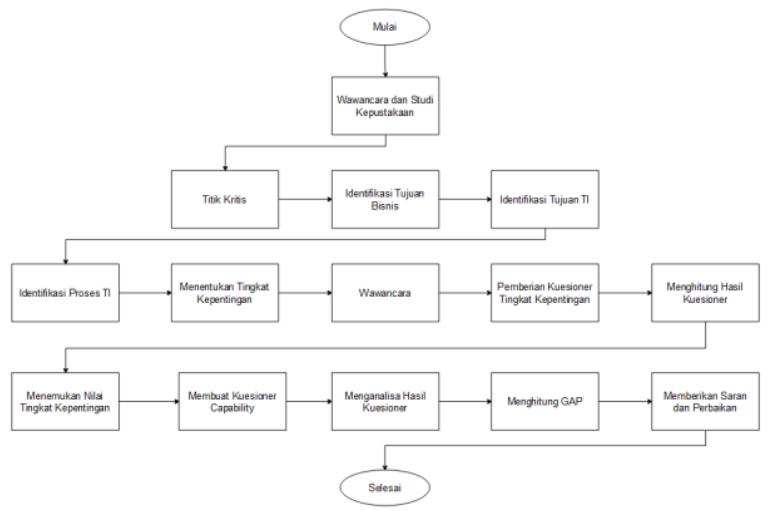

Figure. 1 Audit Research Stages

The service audit stages start from the interview and observation process which are the initial stages in conducting information technology audit research. It aims to find out and observe directly the problems that occur in the company [8]. Interviews are also applied to find out the critical points and objects that are performed by service audits. The second stage is the literature study, which done by collecting data and information through various libraries. The third stage is the core audit process which consists of identifying business objectives, IT objectives and IT processes. The identification of business processes aims to match the point of the company's problems with the business objectives that exist in the COBIT 5 framework. The identification of IT objectives aims to identify the results of business objectives with the IT objectives that are in COBIT 5. The identification of IT processes is the stage to find processes in the existing domain of the IT processes in COBIT 5 from the identification of IT objectives. The fourth stage is drafting importance level questionnaires that are obtained from the identification of IT processes and the company's problem points, as well as calculating the results of the importance level questionnaires to proceed to the next stage.

The fifth stage is compiling a capability questionnaire that is based on the results of the importance level questioners, problem points and the COBIT 5 framework. The sixth stage is the analysis of the results of the capability questionnaire to determine the level of the gap, therefore improvements can be made using the COBIT 5 framework. [6]

\section{CONCEPTS AND THEORIES}

This section contains concepts and theories that support the research. They are including the framework and capability level of COBIT 5. It will be discussed as follows.

\subsection{Framework COBIT 5}

COBIT (Control Objective for Information and Related Technology) is a standard of practice that contains guidelines for management practices and information technology governance in companies. It has gained recognition from all over the world as an effective tool for conducting assessments and implementations in supporting the achievement of information technology governance and management as well as IT capabilities [7]. The latest COBIT 5 which appeared on June 2012 discussed about the management of information technology in companies. It provides a comprehensive framework that helps companies to support the achievement of the information technology governance and technology assets (IT) [2]. COBIT is also a series of documentation and guidelines that lead to IT governance. Therefore, it helps auditors, management, and users to build a bridge between business risk, control needs, and technical issues. [3]

\subsection{The Capability Level of COBIT 5}

COBIT 5 introduces a capability model process which based on ISO / IEC 15504. The capability model is influenced by the organization's business objectives, operating environment and industry practices [4]. It measures the performance of each governance process (EDM-based) or management process (PBRM based), and it can identify areas that need to be improved in performance. The capability that can be achieved by each process consists of six levels, namely:

a. Level 0 Incomplete Process - The process is incomplete; the process was not implemented or failed to achieve its objectives. The level of Incomplete Process has little or no evidence of systematic achievement of the process objectives.

b. Level 1 Performed Process (one attribute) - The process has been performed; the implemented process has succeeded in achieving its objectives.

c. Level 2 Managed Process (two attributes) - The regular process (two attributes); the process has been performed and implemented in a more organized way (planned, monitored, and adjusted), and the output of the resulting process has been determined, controlled, and maintained to the maximum.

d. Level 3 Established Process (two attributes) The process has been implemented by using predetermined SOP standards which are able to achieve the expected outcomes.

e. Level 4 Predictable Process (two attributes) The process is performed by using established SOP standards. The process and results can be predicted within a specified time limit.

f. Level 5 Optimizing Process (two attributes) The performance of the process continues to be improved on an ongoing basis in order to meet current and future business objectives.

Each level of capability can only be achieved when the results obtained at each level must at least be fully achieved with a score range of 85-1005. Furthermore, it can be continued at the next level.

\section{RESULT AND DISCUSSION \\ 5.1 Identification of Business Objectives}

The identification of business processes is the initial stage performed in the information technology audit process. It is done by mapping a critical point towards the business objectives of the COBIT 5 framework. The business objectives of the COBIT 5 framework consist of 17 business objectives. The results of the mapping between critical points and business objectives can be seen in Table 1 . 
Table 1. Critical Mapping of Tabanan Primary Tax Service Offices with COBIT 5 Business Objectives

\begin{tabular}{|c|c|c|c|}
\hline Source & Critical Point & No. & $\begin{array}{l}\text { Business } \\
\text { Objectives }\end{array}$ \\
\hline \multirow{6}{*}{$\begin{array}{l}\text { Tabanan } \\
\text { Primary } \\
\text { Tax } \\
\text { Service } \\
\text { Offices }\end{array}$} & $\begin{array}{l}\text { The taxpayers do } \\
\text { not fill the data } \\
\text { form of annual tax } \\
\text { returns } \\
\text { completely. }\end{array}$ & 7 & $\begin{array}{l}\text { Availability of } \\
\text { sustainable } \\
\text { business } \\
\text { services }\end{array}$ \\
\hline & $\begin{array}{l}\text { Filling out the } \\
\text { form of annual tax } \\
\text { returns } \\
\begin{array}{l}\text { considered is } \\
\text { complicated by } \\
\text { the taxpayer. }\end{array} \\
\end{array}$ & 11 & $\begin{array}{l}\text { Optimization of } \\
\text { business process } \\
\text { functions }\end{array}$ \\
\hline & $\begin{array}{l}\text { The taxpayers } \\
\text { complain of long } \\
\text { queues when } \\
\text { reporting the } \\
\text { annual tax returns. }\end{array}$ & 11 & $\begin{array}{l}\text { Optimization of } \\
\text { business process } \\
\text { functions }\end{array}$ \\
\hline & $\begin{array}{l}\text { The interface of } \\
\text { the E-Filing } \\
\text { application (online } \\
\text { annual tax returns } \\
\text { input) is hard to } \\
\text { understand }\end{array}$ & 11 & $\begin{array}{l}\text { Optimization of } \\
\text { business process } \\
\text { functions }\end{array}$ \\
\hline & $\begin{array}{l}\text { The taxpayers are } \\
\text { in doubt to fill the } \\
\text { tax return online } \\
\text { via the E-Filing } \\
\text { application and } \\
\text { they chose to } \\
\text { come directly to } \\
\text { the office to fill it } \\
\text { manually. As the } \\
\text { result, it slows } \\
\text { down the process } \\
\text { of filing the } \\
\text { annual tax return. }\end{array}$ & 7. & $\begin{array}{l}\text { Availability of } \\
\text { sustainable } \\
\text { business } \\
\text { services }\end{array}$ \\
\hline & $\begin{array}{l}\text { The taxpayer data } \\
\text { access by } \\
\text { employees is still } \\
\text { limited, hence it } \\
\text { slows the process } \\
\text { of checking } \\
\text { taxpayer data that } \\
\text { have dubious and } \\
\text { incompatible data. }\end{array}$ & 11 & $\begin{array}{l}\text { Optimization of } \\
\text { business process } \\
\text { functions }\end{array}$ \\
\hline
\end{tabular}

\subsection{Identification of IT Objectives}

The identification of IT objectives is performed in the information technology audit process after getting the results of mapping critical points with business objectives. The purpose of IT is used to determine the relationship between the critical point with IT objectives. Mapping business goals with IT goals can be seen in Table 2 .

Table 2. Mapping Business Goals with IT Goals

\begin{tabular}{|l|l|l|}
\hline No. & Business Objectives & $\begin{array}{l}\text { IT } \\
\text { Objectives }\end{array}$ \\
\hline 7 & $\begin{array}{l}\text { Availability of sustainable business } \\
\text { services }\end{array}$ & $4,10,14$ \\
\hline 11 & $\begin{array}{l}\text { Optimization of business process } \\
\text { functions }\end{array}$ & 7,12 \\
\hline
\end{tabular}

The mapping of business objectives with IT objectives can be seen in Table 2. The results of the IT objectives mapping obtained are numbers 4, 7, 10, 12 and 14 based on the COBIT 5 framework. An explanation of each IT goal is shown in Table 3.

Table 3. The explanation of IT Objectives

\begin{tabular}{|c|l|}
\hline No. & IT objective obtained \\
\hline 4 & $\begin{array}{l}\text { Dealing with IT issues that is related to business } \\
\text { risk }\end{array}$ \\
\hline 7 & Delivering IT services that suit business needs. \\
\hline 10 & $\begin{array}{l}\text { Information security, infrastructure processing and } \\
\text { applications. }\end{array}$ \\
\hline 12 & $\begin{array}{l}\text { Empowerment and support of business processes } \\
\text { by integrating applications and technology into } \\
\text { business processes. }\end{array}$ \\
\hline 14 & $\begin{array}{l}\text { Availability of reliable and useful information for } \\
\text { decision making. }\end{array}$ \\
\hline
\end{tabular}

The explanation of the results of IT objectives can be seen in Table 3. From the results of mapping IT objectives with business objectives, there were 5 IT objectives obtained with an explanation in each of the process. Then, the objective of IT is used to map the IT process, therefore the results of the IT process focus on the company's critical points.

\subsection{Identification of IT Process}

The identification of IT processes is performed in the information technology audit process after getting the results of mapping business objectives with IT objectives. Mapping to the IT process is used to determine the relationship between IT objectives and the IT process by selecting a domain based on the COBIT 5 framework as shown in Table 4.

Table 4. Mapping IT Objectives with IT Process

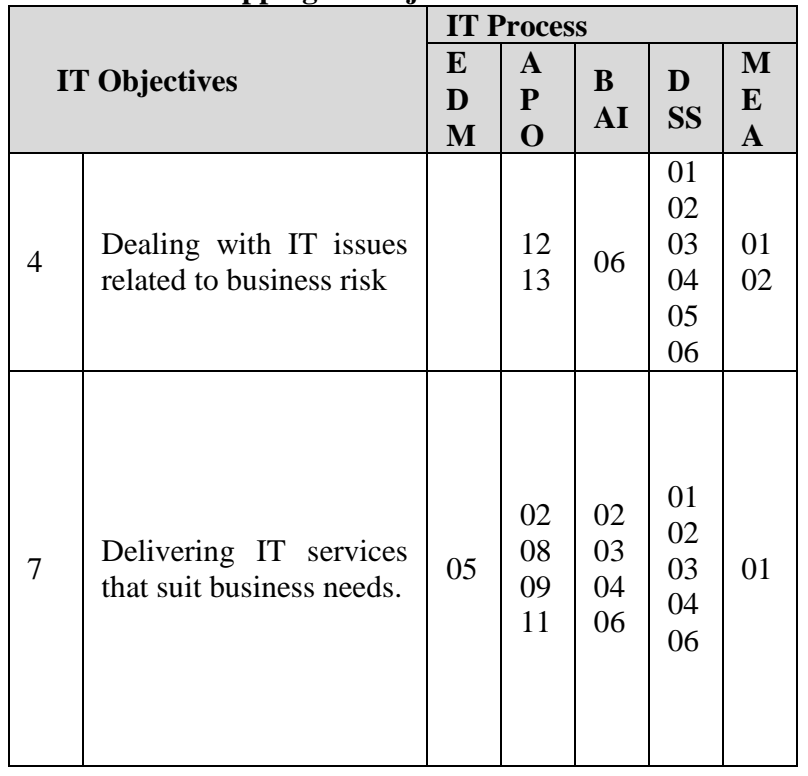




\begin{tabular}{|c|c|c|c|c|}
\hline 10 & $\begin{array}{lr}\text { Information } & \text { security, } \\
\text { infrastructure } & \\
\text { processing } & \text { and } \\
\text { applications. } & \end{array}$ & $\begin{array}{l}12 \\
13\end{array}$ & 06 & 05 \\
\hline 12 & $\begin{array}{lr}\text { Empowerment } & \text { and } \\
\text { support of business } \\
\text { processes by integrating } \\
\text { applications } \\
\text { technology } \\
\text { business processes. }\end{array}$ & 08 & 02 & \\
\hline 14 & $\begin{array}{l}\text { Availability of reliable } \\
\text { and useful information } \\
\text { for decision making. }\end{array}$ & $\begin{array}{l}09 \\
13\end{array}$ & $\begin{array}{l}04 \\
10\end{array}$ & $\begin{array}{l}03 \\
04\end{array}$ \\
\hline
\end{tabular}

The mapping of IT objectives with IT processes is shown in Table 4. From the mapping results obtained, there were 20 out of 37 IT processes based on the COBIT 5 framework.

\subsection{Determination of the RACI Chart}

The determination of level of importance respondents is done by selecting respondents who have an interest in the business process of filing annual tax returns. Determining the respondents who are given the importance level questionnaire is done by making RACI chart. The RACI chart is used to find out the duties and responsibilities of each position in a job. The results of determining The RACI Chart can be seen in Table 5.

Table 5. RACI Chart of Level of Importance Determination

\begin{tabular}{|c|c|c|c|c|c|c|}
\hline RACI & \multicolumn{6}{|c|}{ Entity } \\
\hline $\begin{array}{lr}\mathbf{R}=\quad \text { Responsible (A } \\
\text { person } & \text { who does an } \\
\text { activity) } & \end{array}$ & \multirow[b]{4}{*}{ 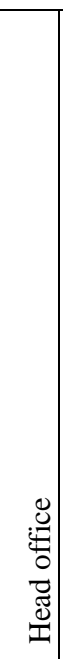 } & \multirow{4}{*}{ 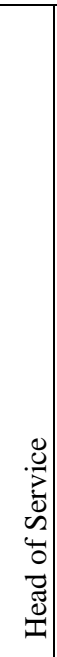 } & \multirow{4}{*}{ 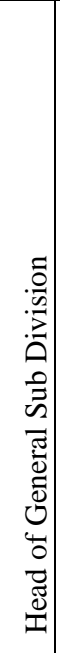 } & \multirow{4}{*}{ 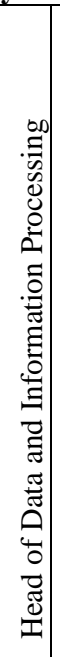 } & \multirow{4}{*}{ 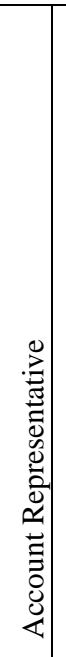 } & \multirow{4}{*}{ 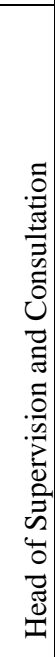 } \\
\hline $\begin{array}{l}\text { A = Accountable } \\
\text { (A person who is } \\
\text { responsible and has an } \\
\text { authority to decide on } \\
\text { a case) }\end{array}$ & & & & & & \\
\hline $\begin{array}{l}\text { C = Consult } \\
\text { (A person whose } \\
\text { feedback or } \\
\text { suggestions are } \\
\text { needed and contribute } \\
\text { to the activity) }\end{array}$ & & & & & & \\
\hline $\begin{array}{l}\text { I } \quad=\text { Inform } \\
\text { (A people who needs } \\
\text { to know the results of } \\
\text { a decision or action) }\end{array}$ & & & & & & \\
\hline $\begin{array}{l}\text { Coordinating the } \\
\text { implementation of } \\
\text { Annual Tax Returns } \\
\text { research that is } \\
\text { submitted beyond the } \\
\text { deadline and a } \\
\text { research in connection } \\
\text { with the Annual Tax } \\
\text { Returns that was not } \\
\text { submitted. }\end{array}$ & $\mathrm{R}$ & I & I & I & I & I \\
\hline
\end{tabular}

\begin{tabular}{|c|c|c|c|c|c|}
\hline $\begin{array}{l}\text { Doing the preparation } \\
\text { of taking the form of } \\
\text { an Annual Income } \\
\text { Tax Return along with } \\
\text { the electronic } \\
\text { application of Annual } \\
\text { Income Tax Return by } \\
\text { the Taxpayer, } \\
\text { administration of the } \\
\text { Annual Tax Return } \\
\text { that has been received } \\
\text { back, and the } \\
\text { provision of Tax } \\
\text { Object Notification }\end{array}$ & A & $\mathrm{R}$ & I & I & I \\
\hline $\begin{array}{l}\text { Developing a draft } \\
\text { concept for improving } \\
\text { SOPs in the Tax } \\
\text { Service } \\
\text { Office environment } \\
\text { that is oriented to the } \\
\text { quality assurance } \\
\text { system. }\end{array}$ & $\mathrm{R}$ & I & A & I & I \\
\hline $\begin{array}{l}\text { Performing a } \\
\text { recording, } \\
\text { management, } \\
\text { improvement, and } \\
\text { utilization of tax data } \\
\text { both systemically and } \\
\text { manually, as well as } \\
\text { implementing tax data } \\
\text { protection. }\end{array}$ & A & I & $\mathrm{R}$ & I & I \\
\hline $\begin{array}{l}\text { Examining the } \\
\text { completeness of the } \\
\text { Annual Tax Returns } \\
\text { and the } \\
\text { terms of delivering the } \\
\text { correction of it. }\end{array}$ & A & I & I & $\mathrm{R}$ & I \\
\hline $\begin{array}{l}\text { Conducting taxation } \\
\text { technical guidance } \\
\text { and consultation to the } \\
\text { public, taxpayers or } \\
\text { their proxies directly } \\
\text { and indirectly }\end{array}$ & $\mathrm{A}$ & I & I & I & $\mathrm{R}$ \\
\hline
\end{tabular}

\subsection{Importance Level Questionnaire}

The importance level questionnaire is used to determine the level of importance that is part of the IT process details to support the IT process in a company. The list of questionnaire statements are determined based on the results of the mapping of IT processes and the company's critical points. The design of the importance level questionnaire can be seen in Table 6 .

Table 6. Importance Level Questionnaire

\begin{tabular}{|c|l|c|c|c|c|c|}
\hline No & \multicolumn{5}{|c|}{ IT Process } \\
\hline \multirow{3}{*}{1} & \multicolumn{4}{|c|}{$\begin{array}{l}\text { EDM 05) Ensuring transparency in company } \\
\text { performance, conformity measurement and reporting, } \\
\text { therefore the relationship between stakeholders is } \\
\text { effective and in time. }\end{array}$} \\
\cline { 2 - 6 } & $\begin{array}{l}\text { The Level of } \\
\text { Importance }\end{array}$ & STP & TP & CP & P & SP \\
\hline \multirow{2}{*}{2} & $\begin{array}{l}\text { (APO 2) Aligning strategic IT plans with business } \\
\text { objectives, and communicating those objectives, } \\
\text { therefore they can be understood by all stakeholders. }\end{array}$ \\
\cline { 2 - 7 } & $\begin{array}{l}\text { The Level of } \\
\text { Importance }\end{array}$ & STP & TP & CP & P & SP \\
\hline 3 & \begin{tabular}{l} 
APO 8) Ensuring transparency between business \\
\hline
\end{tabular}
\end{tabular}




\begin{tabular}{|c|c|c|c|c|c|}
\hline \multicolumn{6}{|c|}{$\begin{array}{l}\text { objectives and the information technology application, } \\
\text { therefore it can run well and achieve optimal goals. }\end{array}$} \\
\hline $\begin{array}{l}\text { The Level of } \\
\text { Importance }\end{array}$ & STP & TP & $\mathrm{CP}$ & $\mathrm{P}$ & SP \\
\hline
\end{tabular}

The importance level questionnaire consisted of 20 statements related to the company's critical point and the IT process of mapping results that had been carried out previously. It aims to find out the opinion of the top brass of the organization regarding the importance of each IT process. There are 5 choices of the level of importance that must be answered by the respondent, such as very unimportant (STP), unimportant $(\mathrm{TP})$, quite important $(\mathrm{CP})$, important $(\mathrm{P})$ and very important (SP).

\subsection{Capability Level Questionnaire}

The capability level questionnaire contains a statement about the IT process domain that has been adjusted to the critical point and documents from COBIT 5. It aims to determine the maturity of each domain that was given the statement. The capability level questionnaire was given to the company's top level management. The capability level questionnaire design can be seen in Table 7 .

Table 7. Example of Capability Level Questionnaire

\begin{tabular}{|c|c|c|}
\hline \multirow[t]{2}{*}{ No. } & \multirow[t]{2}{*}{ Level } & $\begin{array}{l}\text { Point of Problem: } \\
\text { Taxpayer data access by employees is still } \\
\text { limited, hence it slows the process of } \\
\text { checking taxpayer data that } \\
\text { has dubious and incompatible data. }\end{array}$ \\
\hline & & $\begin{array}{l}\text { Process: DSS 05 } \\
\text { Protecting company information to } \\
\text { maintain the level of information security } \\
\text { risks that can be accepted by companies in } \\
\text { accordance with security policies. } \\
\text { Establishing and maintaining information } \\
\text { security and access rights, as well as } \\
\text { conducting security monitoring. }\end{array}$ \\
\hline 1. & 1.1 & $\begin{array}{l}\text { a) Network and communication } \\
\text { security meets the needs of the } \\
\text { company. } \\
\text { b) Information is processed, stored } \\
\text { and disseminated through } \\
\text { protected devices. } \\
\text { c) All users or employees have a } \\
\text { personal account and access } \\
\text { rights in business processes. } \\
\text { d) Protecting information from } \\
\text { unauthorized access, breakdown, } \\
\text { and interference during the } \\
\text { process. } \\
\text { e) Electronic information is well- } \\
\text { protected when stored, } \\
\text { transferred or destroyed. }\end{array}$ \\
\hline 2. & 2.1 & $\begin{array}{l}\text { a) The purpose of a process } \\
\text { performance is identified } \\
\text { b) The performance of the planned } \\
\text { and supervised process } \\
\text { c) The performance of the process } \\
\text { that is changed to meet the needs } \\
\text { d) The responsibility and authority } \\
\text { to carry out the process are } \\
\text { defined, assessed and } \\
\text { communicated. } \\
\text { e) Resources and information that } \\
\text { are needed for the process are } \\
\text { defined, assessed and }\end{array}$ \\
\hline
\end{tabular}

\begin{tabular}{|c|c|c|c|}
\hline & & & communicated. \\
\hline 3. & 2.2 & a) & $\begin{array}{l}\text { The need for work from a } \\
\text { process is defined } \\
\text { The need for documentation and } \\
\text { control of work is defined } \\
\text { Work products are properly } \\
\text { identified, registered and } \\
\text { controlled }\end{array}$ \\
\hline
\end{tabular}

The capability level questionnaire design in Table 7 shows the questionnaire in the DSS 05 domain. Each domain has a statement that must be filled in by the respondent by giving a value of 0-100. The questionnaire results are calculated based on the average at each level of the capability questionnaire.

\subsection{Maturity Level Analysis}

The analysis of maturity level is used to determine gaps in each IT process. The gap is obtained by looking at the current capability and expected capability in each of the capability questionnaires of IT process. Table 8 shows the results of capability level maturity.

\section{Table 8. The results of Capability Level Gaps}

\begin{tabular}{|c|c|c|c|}
\hline $\begin{array}{c}\text { IT } \\
\text { Process }\end{array}$ & $\begin{array}{c}\text { Current } \\
\text { Capability } \\
\text { (CC) }\end{array}$ & $\begin{array}{c}\text { Expected } \\
\text { Capability } \\
\text { (EC) }\end{array}$ & $\begin{array}{c}\text { GAP } \\
\text { (EC - } \\
\text { CC) }\end{array}$ \\
\hline DSS02 & 3 & 5 & 2 \\
\hline DSS03 & 3 & 5 & 2 \\
\hline DSS05 & 3 & 5 & 2 \\
\hline APO12 & 3 & 5 & 2 \\
\hline
\end{tabular}

Table 8 is a table of the results of the current capability level gap where it is obtained from the results of the Current Capability (CC) questionnaire, the capability expected by the organization or company in table 4.17 (Expected Capability (EC) and the gap level of expected capability minus current capability.

\subsection{Recommendations for Improvement}

Analysis of recommendations for improvement is given to the 4 capability domains. Existing condition, expected condition and recommendations for improvement are given based on the COBIT 5 framework. The analysis of recommendations for improvement can be seen in Table 9 .

\begin{tabular}{|l|l|l|}
\hline $\begin{array}{l}\text { Existing } \\
\text { Condition }\end{array}$ & $\begin{array}{l}\text { Expected } \\
\text { Condition }\end{array}$ & Recommendation \\
\hline $\begin{array}{l}\text { The interface of } \\
\text { e-filing } \\
\text { application is } \\
\text { not easily } \\
\text { understood by } \\
\text { taxpayers (DSS } \\
\text { 02) }\end{array}$ & $\begin{array}{l}\text { improvement in } \\
\text { the e-filing } \\
\text { application } \\
\text { interface in order } \\
\text { to facilitate } \\
\text { taxpayers in } \\
\text { filing the annual } \\
\text { tax return, as the } \\
\text { result there is no } \\
\text { error in filing the } \\
\text { data }\end{array}$ & $\begin{array}{l}\text { It recommended } \\
\text { to Tabanan Primar } \\
\text { Office to change } \\
\text { the e-filing } \\
\text { application therface into the } \\
\text { one that can be } \\
\text { easily understood } \\
\text { by taxpayers as } \\
\text { users. In addition, } \\
\text { creating user } \\
\text { guides that can } \\
\text { help taxpayers if } \\
\text { they have difficulty } \\
\text { in understanding } \\
\text { the filing form. }\end{array}$ \\
\hline $\begin{array}{l}\text { Long queues } \\
\text { during }\end{array}$ & $\begin{array}{l}\text { There is an } \\
\text { evaluation of the }\end{array}$ & $\begin{array}{l}\text { It is recommended } \\
\text { to }\end{array}$ \\
\hline
\end{tabular}




\begin{tabular}{|c|c|c|}
\hline $\begin{array}{l}\text { Annual Tax } \\
\text { Return reporting } \\
\text { process } \\
\text { complained by } \\
\text { taxpayers. (DSS } \\
\text { 03) }\end{array}$ & $\begin{array}{l}\text { problems that } \\
\text { cause long } \\
\text { queues during } \\
\text { the Annual Tax } \\
\text { Returns reporting } \\
\text { process which } \\
\text { takes a long } \\
\text { time. }\end{array}$ & $\begin{array}{l}\text { the Tabanan Primar } \\
\text { y Tax Service } \\
\text { Office to do an } \\
\text { evaluation of the } \\
\text { problems that } \\
\text { cause long queues. } \\
\text { In addition, } \\
\text { conducting training } \\
\text { for employees who } \\
\text { handle the Annual } \\
\text { Tax Returns } \\
\text { reporting process } \\
\text { to be able to work } \\
\text { more quickly and } \\
\text { efficiently. }\end{array}$ \\
\hline $\begin{array}{l}\text { Taxpayer data } \\
\text { access by } \\
\text { employees is } \\
\text { still limited, } \\
\text { hence it slows } \\
\text { the process of } \\
\text { checking } \\
\text { taxpayer data } \\
\text { that is beyond } \\
\text { the limits (DSS } \\
\text { 05) }\end{array}$ & $\begin{array}{l}\text { There is an } \\
\text { evaluation of the } \\
\text { taxpayer's data } \\
\text { access rights of } \\
\text { employees in } \\
\text { order to speed up } \\
\text { the process of } \\
\text { checking } \\
\text { taxpayer data } \\
\text { that beyond the } \\
\text { limits, hence it } \\
\text { speeds up the } \\
\text { input process }\end{array}$ & $\begin{array}{l}\text { It is recommended } \\
\text { to } \\
\text { the Tabanan Primar } \\
\text { y Tax Service } \\
\text { Office to do an } \\
\text { evaluation of the } \\
\text { problems in the } \\
\text { process } \\
\text { checking taxpayer } \\
\text { data in order to } \\
\text { make the input } \\
\text { process to be faster } \\
\text { and more efficient. }\end{array}$ \\
\hline
\end{tabular}

\section{CONCLUSION}

As the final results of the service audit in filing annual tax returns at the Tabanan Primary Tax Service Office by using the COBIT 5 framework, there are four domains that become the evaluation points, namely DSS 02, DSS 03, DSS 05, and APO 12 with current capability at level 3 (established process), and all domains have expected capability at level 5 (optimizing process). In addition, there are recommendations for improvement and expected conditions given to achieve expected capability at level 5 with the PAM Using COBIT 5 Toolkit-Self Assessment Templates as additional suggestions and improvements.

\section{REFERENCES}

[1] N. P. S. M. Suryani dan I. K. A. Purnawan, "Audit of accounting information system using COBIT 4.1 focus on deliver and support domain," Journal of Theoretical and Applied Information Technology, vol. 78, no. 3, hal. 456-463, 2015.

[2] N. K. R. W. Utami, I. P. A. Bayupati, dan I. K. A. Purnawan, "EAM Capability Audit Using COBIT 5 and ISO 55002 at the State Electricity Company (In Indonesia: Audit Capability EAM menggunakan COBIT 5 dan ISO 55002 pada Perusahaan Kelistrikan Negara)," Jurnal Ilmiah Merpati Universitas Udayana, vol. 4, no. 3, hal. 195-204, 2016.

[3] I. W. P. Bharaditya, I. M. Sukarsa, dan P. W. Buana, "Internal Control Improvement for Creating Good Governance," International Journal of Information Engineering and Electronic Business, vol. 9, no. 3, hal. 9-17, 2017.
[4] A. D. Purba, I. K. A. Purnawan, dan I. P. A. E. Pratama, "IT Security Audit Using ISO / IEC 27002 Standard with COBIT 5 (In Indonesia: Audit Keamanan TI Menggunakan Standar ISO / IEC 27002 dengan COBIT 5)," Jurnal Ilmiah Merpati Universitas Udayana, vol. 6, no. 3, hal. 148-158, 2018.

[5] I. K. A. Purnawan, "Information Technology Governance Guidelines Using IT Governance Design Framework (Cobit) at PT. X (In Indonesia: Pedoman Tata Kelola Teknologi Informasi Menggunakan It Governance Design Frame Work (Cobit) pada PT. X)," Lontar Komputer , hal. 200, 2017.

[6] I. N. Putra, A. Hakim, S. H. Pramono, dan H. Tolle, "Adopted COBIT-5 framework for system design of Indonesia navy IS/IT: An evaluation," International Journal of Applied Engineering Research, vol. 12, no. 17, hal. 6420-6427, 2017.

[7] I. P. A. A. Putra, I. M. Sukarsa, dan I. P. A. Bayupati, "IT Performance Management Audit Pt. X with the Cobit 4.1 Framework (In Indonesia: Audit Ti Kinerja Manajemen Pt. X dengan Framework Cobit 4.1)," Lontar Komputer, vol. 6, no. 1, hal. 13-24, 2015.

[8] ISACA, A Business Framework for the Governance and Management of Enterprise IT. 2015. 